\title{
Molecular Identification of Fusarium spp. from Wilt-infected Tomato and Brinjal Plants in Selected Regions of Sri Lanka and Endophytic Bacteria as a Potential Option for Disease Management
}

\author{
W.A.P.G. Weeraratne* and D.M. De Costa ${ }^{1}$ \\ Postgraduate Institute of Agriculture \\ University of Peradeniya \\ Sri Lanka
}

\begin{abstract}
Fusarium wilt caused by Fusarium spp. is an economically important fungal disease of tomato and brinjal production areas in Sri Lanka. The study was carried out to identify Fusarium isolates infecting tomato and brinjal, and endophytic antagonists bacteria against Fusarium wilt pathogen. The infected tomato and brinjal samples were collected from farmers' fields in Matale, Kandy, Nuwara Eliya and Badulla districts and PCR was conducted using primers specific for species, races and formae speciales. Eight, nine and five isolates were identified as Fusarium solani, Fusarium oxysporum $f$. sp. lycopersici race 1 and Fusarium oxysporum $f$. sp. radicis-lycopersici, respectively from the wilt-infected tomato and brinjal collected from the four districts. Thirty endophytic bacterial isolates were isolated from healthy tomato and brinjal stems were antagonistic against Fusarium oxysporum $f$. sp. lycopersici and Fusarium solani. Molecular identification revealed that Pseudomonas geniculata strain ICPH-14, Pseudomonas sp. strain SB 904 (E7), Delftia tsuruhatensis strain MTQ 1, Stenotropomonas maltophilia strain ATCC 13637, Stenotropomonas pavanii strain ICB 89, and Bacillus velezensis strain C19 were among the potential endophytic antagonists.
\end{abstract}

Keywords: Antagonism, endophytes, formae speciales, Fusarium, 16S rRNA

\section{INTRODUCTION}

Fusarium wilt caused by Fusarium oxysporum and Fusarium solani is an economically important fungal disease of Solanaceous crops throughout the world. As F. oxysporum species are phylogenetically diverse and well known as a mycotoxin producer, its precise identification is of prime concern (Irzykowska et al., 2012). Fusarium oxysporum has two important pathogenic formae speciales, namely, F. oxysporum f. sp. lycopersici (FOL) which is grouped into three races (1, 2 and 3 ) and $F$. oxysporum f. sp. radicis-lycopersici (FORL) causing Fusarium wilt and Fusarium crown and root rot, respectively and have been encountered more frequently in tomato-producing countries (Can et al., 2004). Identification of Fusarium species is traditionally based on fungal morphology. It is time-consuming and requires taxonomical expertise (Khosrow, 2016). Molecular markers are technically easy to use, informative and presents conclusive results in the identification of species and subspecies of fungi. The control of Fusarium wilt of tomato (S. lycopersicum L.) and brinjal (S. melongena L.) is difficult due to expression of field symptoms at a later stage of crop

\footnotetext{
${ }^{1}$ Department of Agricultural Biology, Faculty of Agriculture, University of Peradeniya, Sri Lanka

* Corresponding author: gethweeraratne@gmail.com
} 
growth and it shows limited effectiveness to synthetic fungicides. Moreover, the survival of its resting structures, i.e., chlamydospores in the soil for many years without a host, and limits the suppressive effect of crop rotation (Vethavalli and Sudha, 2012). Biological control using endophytic bacteria is one of the alternative control methods used in integrated plant diseases management, supporting agricultural sustainability (Purnawati et al., 2014). Endophytic bacteria live in various tissues and organs of healthy plants. They establish a mutualistic relationship with the plants through many mechanisms to adapt to their living environments and enhance resistance to disease by producing several compounds that promote growth of plants (Gao et al., 2010). So far in Sri Lanka, very few studies related to biological control of root and stem rots of annual crops have been reported, and they have been focused on root rot of bean and root and stem rot of cucumber (Abeysinghe, 2007). However, no attempts have been made in Sri Lanka to explore the potential of endophytic bacteria to use as a biological control agent against vascular pathogens in general or in Fusarium wilt of Solanaceous crops in particular.

Molecular identification of species and subspecies of causal fungi associated with Fusarium wilt of Solanaceous crops in Sri Lanka has become a prime concern as it aids in effective disease management. The objectives of the present study were; (i) isolatation and molecular identification of the causal pathogens of Fusarium wilt of selected Solanaceous crops cultivated in Sri Lanka, (ii) isolation and identification of indigenous endophytic bacteria at molecular level, and (iii) to assess the efficacy of endophytic bacterial isolates against Fusarium wilt causing pathogen/s under in vitro conditions.

\section{MATERIALS AND METHODS}

\section{Collection of plant samples}

A total of 90 plant samples (42 brinjal and 48 tomato) showing leaf yellowing, wilting and root rot-like symptoms were collected from farmers' fields at various locations of major Solanaceous growing areas namely Kandy, Matale, Nuwaraeliya and Badulla districts in Sri Lanka during January to June 2017 (Table 1). Disease incidence and field symptoms of affected plants from different locations were recorded.

Table 1. Details of the plant samples showing wilt symptoms collected from various locations

\begin{tabular}{lllll}
\hline \multirow{2}{*}{ District } & \multicolumn{1}{c}{ Locations of sample collection } & \multicolumn{3}{c}{ No. samples collected } \\
\cline { 3 - 5 } & & Tomato & Brinjal & Total No. \\
\hline Kandy & $\begin{array}{l}\text { Gannoruwa, Marassana, Galaha, } \\
\text { Manikhinna, , Madamahanuwara }\end{array}$ & 24 & 13 & 37 \\
Madawala ulpotha, Naula & & & 13 \\
Badulla & $\begin{array}{l}\text { Haththotamuna, Pallepola } \\
\text { Bandarawela, Divithotawela, } \\
\text { Keppetipola }\end{array}$ & 12 & 11 & 23 \\
Nuwara Eliya & $\begin{array}{l}\text { Hanguranketha, Rahangala, } \\
\text { Mandaramnuwara }\end{array}$ & 7 & 10 & 17 \\
\hline Total & & 48 & 42 & 90 \\
\hline
\end{tabular}




\section{Isolation of Fusarium spp.}

Fusarium spp. were isolated from vascular tissues of stems of wilted tomato and brinjal plants. Affected stems of the collected plant samples were washed under running tap water to remove dirt and soil particles. The stems were split lengthwise and cut into thin small pieces $(\leq 1 \mathrm{~cm})$. The cut pieces were surface sterilized with $70 \%$ ethanol for two minutes then rinsed with sterile distilled water. Cut pieces were placed on PDA medium amended with Amoxicillin (500 g/L) to suppress bacterial growth and were incubated at room temperature $\left(28{ }^{\circ} \mathrm{C} \pm 2\right.$ ) for 1 -2 days. After 2 days, sub culturing was done to obtain pure cultures of Fusarium. All the isolates were maintained as axenic cultures by single spore isolation and those purified isolates were kept at $4{ }^{\circ} \mathrm{C}$ by culturing them on PDA slants for further use.

\section{Confirmation of Pathogenicity}

Pathogenicity of 79 Fusarium isolates which were obtained from either tomato or brinjal was tested using tomato (var. Thilina) and brinjal (var. Thinnaweli purple). The seedlings were transplanted in plastic pots (8 cm diameter) containing a sterilized soil mixture (1:1 top soil : compost) under greenhouse conditions at Horticultural Crops Research and Developmental Institute, Gannoruwa. A set of 20 days old ten seedlings of tomato and brinjal, which were, were inoculated separately with each Fusarium isolate at a concentration of $1 \times 10^{6}$ (spores/mL) adopting a root inoculation technique (Maitlo et al., 2016). Another set of 20 days old seedlings $(n=10)$ were inoculated with sterile distilled water to serve as the control. Disease incidence (DI) was recorded as the percentage of infected plants. Disease severity (DS) was assessed as number of plants affected using a visual disease scale of $0-2$, where $0=$ no symptoms, 1 = leaf yellowing, without wilt, 2 = yellowing, wilt, vascular discoloration and dead (Pavlou and Vakalounakis, 2005). The plants were observed for the development of wilt symptoms at weekly intervals after inoculation. Wilted plants which were randomly selected were used for re-isolation of the pathogen and pathogenicity was confirmed according to Koch's postulates.

\section{DNA extraction}

Genomic DNA was extracted from 22 pathogenic Fusarium isolates (as determined by the Koch's postulates) using CTAB procedure (Grover et al., 2012). These 22 pathogenic isolates of Fusarium represented the two wilt-infected crops and the four districts. Extracted genomic DNA of the 22 isolates were subjected to PCR using species and race specific primers (Table 2) as described by Hirano and Arie (2006).

\section{PCR conditions}

PCR amplification was performed with specific primer sets (Table 2) and the reaction mixture contained a total volume of $10 \mu \mathrm{l}$ of PCR master mixture (25 units Taq DNA polymerase, $200 \mu \mathrm{M}$ of each $\mathrm{dNTP}$ and $1 \times$ PCR buffer and $1.5 \mathrm{mM} \mathrm{MgCl}_{2}$ ) (Promega, USA), $0.8 \mu \mathrm{l}$ of each primer (10 mM), $0.5 \mu \mathrm{l}$ of diluted (1:10) DNA template and $2.9 \mu \mathrm{l}$ of sterilized distilled water. PCR program included an initial denaturation of 5 min at $94{ }^{\circ} \mathrm{C}$, followed by 35 cycles of $1 \mathrm{~min}$ at $94{ }^{\circ} \mathrm{C}, 1 \mathrm{~min}$ at $55{ }^{\circ} \mathrm{C}$ and $1 \mathrm{~min}$ at $72{ }^{\circ} \mathrm{C}$ with a final extraction at $72{ }^{\circ} \mathrm{C}$ for $10 \mathrm{~min}$. PCR products were resolved in $2 \%$ agrose gel for $45 \mathrm{~min}$ at $80 \mathrm{~V}$ and visualized with a gel documentation system (ENDURO ${ }^{\mathrm{TM}}$ GDS, USA). G $571 \mathrm{~A} 1 \mathrm{~kb}$ ladder (Promega, USA) was used as a DNA size marker. 
Table 2. Primers used in the study to identify species, forma speciales and races of Fusarium

\begin{tabular}{llll}
\hline \multicolumn{1}{c}{$\begin{array}{c}\text { Primer } \\
\text { code }\end{array}$} & \multicolumn{1}{c}{$\begin{array}{c}\text { Primer sequence } \\
\left(\mathbf{5}, \rightarrow \mathbf{3}^{\prime}\right)\end{array}$} & $\begin{array}{c}\text { Expected } \\
\text { product size } \\
(\mathbf{b p})\end{array}$ & \multicolumn{1}{c}{ Specificity* } \\
\hline uni-f & ATCATCTTGTGCCAACTTCAG & $670-672$ & F. oxysporum \\
uni-r & GTTTGTGATCTTTGAGTTGCCA & & FOL (races 1 and 3) \\
sp13-f & GTCAGTCCATTGGCTCTCTC & 445 & FOL (races 2 and 3) \\
sp13-r & TCCTTGACACCATCACAGAG & & FORL \\
sp 23-f & CCTCTTGTCTTTGTCTCACGA & 518 & F. solani \\
sp 23-r & GCAACAGGTCGTGGGGAAAA & & \\
sprl-f & GATGGTGGAACGGTATGACC & 947 & \\
sprl-f & GATGGTGGAACGGTATGACC & & \\
TEF-Fu3f & GGTATCGACAAGCGAACCAT & $\sim 400$ & \\
TEF-Fu3r & TAGTAGCGGGGAGTCTCGAA & & \\
\hline * FOL - F. oxysporum f.sp. lycopersici FORL- $F$. oxysporum f. sp. radicis-lycopersici &
\end{tabular}

\section{DNA sequencing and homology search}

The resulted in PCR products were sequenced at Asiri Centre for Genomic and Regenerative Medicine, Asiri Surgical Hospital, Colombo 5, Sri Lanka and were subjected to DNA homology search with available nucleotide databases (BLAST; http: www.ncbi.nlm.gov/ BLAST/).

\section{Isolation of endophytic bacteria}

Solanaceous plants having no visible symptoms were also collected from the locations from where wilt-infected plants were collected to isolate bacterial endophytes. Isolation was done using stems of 40 healthy brinjal and tomato plants collected from farmers' fields. The stem of each plant was initially washed under tap water for $10 \mathrm{~min}$, to remove adhering soil particles and subsequently was rinsed three times with sterilized distilled water. The base of the stems of each healthy plant was cut into small pieces and surface sterilized by immersing in $70 \%$ ethanol for 1-2 min, followed by two washes in sterile distilled water. After blot drying each part was placed on nutrient agar (NA) medium and was incubated at room temperature $\left(28{ }^{\circ} \mathrm{C} \pm 2{ }^{\circ} \mathrm{C}\right)$ for 24 - $48 \mathrm{hr}$. Single bacterial colonies were isolated following streak plate technique. Pure isolates of bacteria were preserved in $15 \%$ glycerol and stored at $-80{ }^{\circ} \mathrm{C}$. Isolates of the endophytic bacteria were characterized following conventional methods including colony appearances and biochemical properties. To differentiate Gram positive and negative bacteria, a loop full of each isolated bacterium was placed on a glass slide with a drop of $3 \%(\mathrm{v} / \mathrm{v}) \mathrm{KOH}$ solution, stirred for 10 seconds and was observed for the formation of slime threads (Purnawati et al., 2014).

\section{In vitro screening of antagonistic endophytic bacteria against pathogenic Fusarium} isolates

Thirty different isolates of endophytic bacteria were preliminarily screened for the in vitro antagonistic activity against two pathogenic Fusarium isolates (representing a highly pathogenic isolate from each crop, based on pathogenicity test) by dual-culture technique on 
Potato Dextrose Agar (PDA) with some modifications. Briefly, the mycelial plug of $5 \mathrm{~mm}$, pathogenic fungus collected from the edge of actively growing colonies were placed on the center of the plates containing fresh PDA medium. A loopful of each endophytic bacterial isolates (from 1-day old culture) was streaked on three sides opposite to the fungal disc at a distance of $10 \mathrm{~mm}$ from the edge of the plate. The plates inoculated with the pathogen alone were maintained as control. Each treatment (i.e. endophytic bacterial isolates) was replicated six times according to a complete randomized design. The plates were incubated at room temperature $\left(28 \pm 2{ }^{\circ} \mathrm{C}\right)$ for seven days. The percent inhibition of growth of each Fusarium isolate was calculated in comparison to the fungal growth in control plates. Colony growth of each Fusarium isolate was recorded and percent inhibition of fungus (growth reduction over control) was calculated by using following formula (Vethavalli and Sudha, 2012).

$\mathrm{I}=[(\mathrm{C}-\mathrm{T}) / \mathrm{C}] \times 100$

where, $\mathrm{I}$ is the percentage inhibition of mycelial growth, $\mathrm{C}$ is the radial growth of fungus in the control and $\mathrm{T}$ is radial growth of the pathogen in treatment. Data were analyzed using analysis of variance (ANOVA) for the completely randomized design, and mean separation was performed using Fisher's Protected Least Significant Difference (LSD) method.

\section{Extraction of genomic DNA from endophytic bacteria}

Bacterial DNA was extracted from six effective endophytic bacterial isolates as determined by the in vitro antagonistic test according to the modified protocol by Sun et al. (2008). The quality of the DNA obtained from six endophytic bacterial isolates was verified on a $1 \%$ agarose gel.

\section{Molecular identification of endophytic bacteria}

The 16S rRNA gene was amplified using universal primers 27F (5'AGAGTTTGATCMTGGCTCAG-3') and 492R (5'-TACGGYTACCTTGTTACGACTT-3') which will amplify an approximately 1500 bp PCR product (Sun et al., 2008). PCR amplification was done with an initial denaturation at $94{ }^{\circ} \mathrm{C}$ for 4 min followed by 35 cycles of 1 min denaturation at $94{ }^{\circ} \mathrm{C}, 1 \mathrm{~min}$ annealing at $58^{\circ} \mathrm{C}, 1 \mathrm{~min}$ extension at $72{ }^{\circ} \mathrm{C}$ and final extension step was $10 \mathrm{~min}$ at $72{ }^{\circ} \mathrm{C}$. The PCR products obtained by amplification were analyzed on a $2 \%(\mathrm{w} / \mathrm{v})$ agarose gel and the PCR products were sequenced at Asiri Centre for Genomic and Regenerative Medicine, Asiri Surgical Hospital, Colombo 5, Sri Lanka. A homology search with the 16S rDNA sequences of the isolates were performed using BLAST program from GenBank database (http: www.ncbi.nlm.gov/ BLAST/).

\section{RESULTS AND DISCUSSION}

\section{Isolation of causal pathogens of Fusarium wilt}

Most of the tomato and brinjal fields showed infection at a later stage of the crop growth and the disease incidence ranged from 10-70\%. Few tomato fields at Manikhinna, Galaha and Mandaramnuwara reported infected plants at an early stage of the crop growth (2-3 weeks after transplanting) with $>50 \%$ disease incidence showing leaf yellowing, wilting and root rot symptoms and was suspected as Fusarium crown and root rot disease. A total of 79 Fusarium isolates were successfully recovered from disease stems of tomato and brinjal plants collected from 90 field samples. Out of 79 Fusarium isolates, 34 isolates were from 
Kandy, 22 were from Nuwara Eliya, 12 were from Matale and 11 were from Badulla districts.

\section{Confirmation of pathogenicity}

The results of the pathogenicity tests carried out with the two crops using 79 Fusarium isolates are presented in Table 3. The Fusarium isolates were categorized into four groups viz., Highly pathogenic (19 isolates), Moderately pathogenic (23), low pathogenic (31) and Non-pathogenic (six isolates) based on disease severity scale of Pavlou and Vakalounakis (2005). All isolates were successfully re-isolated from the plants showing wilt symptoms and confirmed the pathogenicity of each Fusarium isolate.

Table 3. Pathogenic variation of 79 Fusarium isolates based on pathogenicity test

\begin{tabular}{lccccc}
\hline District & $\begin{array}{c}\text { Total } \\
\text { isolates }\end{array}$ & \multicolumn{4}{c}{ No. of isolates } \\
\cline { 3 - 6 } & tested & $\begin{array}{c}\text { Non- } \\
\text { pathogenic }\end{array}$ & $\begin{array}{c}\text { Low } \\
\text { pathogenic }\end{array}$ & $\begin{array}{c}\text { Moderately } \\
\text { pathogenic }\end{array}$ & $\begin{array}{c}\text { Highly } \\
\text { pathogenic }\end{array}$ \\
\hline Matale & 12 & 0 & 4 & 2 & 6 \\
Kandy & 34 & 4 & 14 & 11 & 5 \\
Badulla & 14 & 0 & 3 & 4 & 4 \\
Nuwaraeliya & 3 & 2 & 12 & 6 & 4 \\
\hline Total & 79 & 6 & 31 & 23 & 19 \\
\hline
\end{tabular}

\section{Molecular identification of selected Fusarium spp}

Out of the 22 Fusarium isolates obtained from wilt-infected tomato and brinjal plants representing the four districts, 14 gave PCR products of approximately 675 bp with universal primers (uni-f and uni-r) confirming $F$. oxysporium (Figure 1). The ITS region was successfully amplified by the fungal-specific universal primer pairs TEF-Fu3f and TEF-Fu3r and expected PCR product of $\sim 400$ bp (Figure 2) was obtained by the other eight Fusarium isolates, confirming that they are F. solani.

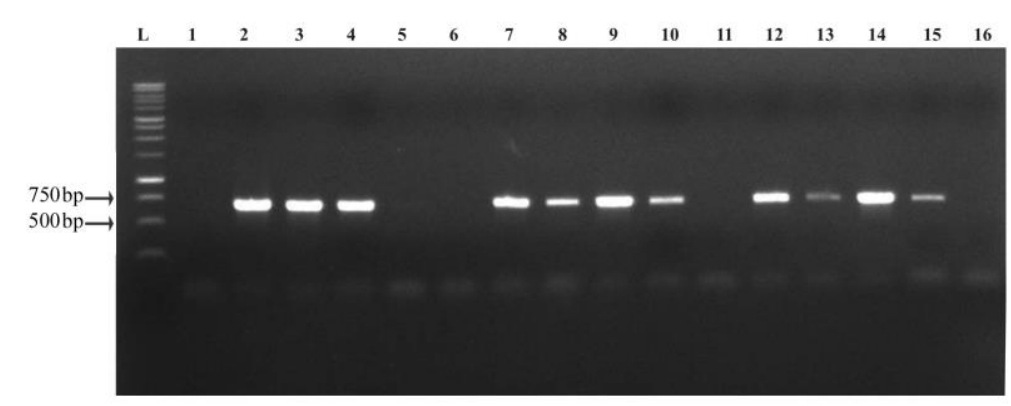

Figure 1. PCR amplicons of uni-f and uni-r primers for $F$. oxysporum

Lanes L: DNA size marker, 1: Fu1, 2: Fu33, 3: Fu 34, 4: Fu 37, 5: Fu 40, 6:

Fu 10, 7: Fu 22, 8: Fu 23, 9: Fu 29, 10: Fu 60, 11: Fu 11, 12: Fu 12, 13: Fu19, 14: Fu 20, 15: Fu 76, 16: negative control (Water) 


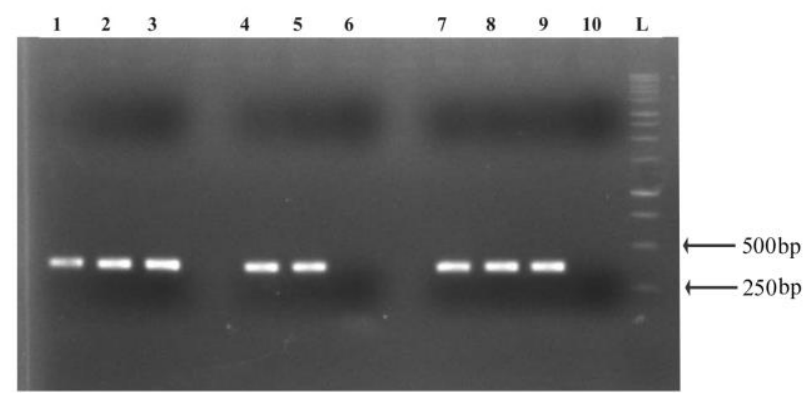

Figure 2. PCR amplicons of TEF-Fu3f and TEF-Fu3r primers for F. solani

Lanes L: DNA size marker, 1: Fu 1, 2: Fu 38, 3: Fu 40, 4: Fu 2, 5: Fu 10, 6:

Fu 22, 7: Fu 11, 8: Fu 17, 9: Fu 71, 10: negative control (water)

Among the $14 \mathrm{~F}$. oxysporium isolates, five isolates, namely two (i.e. Fu22 and Fu25) from Manikkhinna area of Kandy district, Fu32 from Haththotaamuna of Matale district, Fu 19 from Helahalpae of Badulla district and Fu76 from Labuhena of Nuwaraeliya district resulted in PCR amplicons of an approximate size of $947 \mathrm{bp}$ with sprl primers and they were identified as $F$. oxysporum f. sp. radicis-lycopersici (Figure 3). Remaining nine $F$. oxysporium isolates (four from Matale, two from Kandy and two from Badulla districts) gave PCR amplicons of 445 bp with sp13 primers specific to $F$. oxysporium f. sp. lycopersici (FOL) races 1 and 3 (Figure 4). However, none of the above nine F. oxysporium isolates gave fragments with sp23 primers (FOL, races 2 and 3). It was confirmed that all nine isolates belong to $F$. oxysporium f. sp. lycopersici (FOL) race 1 . This is the first study to report the identification of the $F$. oxysporium f. sp. lycopersici (FOL) race 1 from Solanaceous crops grown in Sri Lanka.

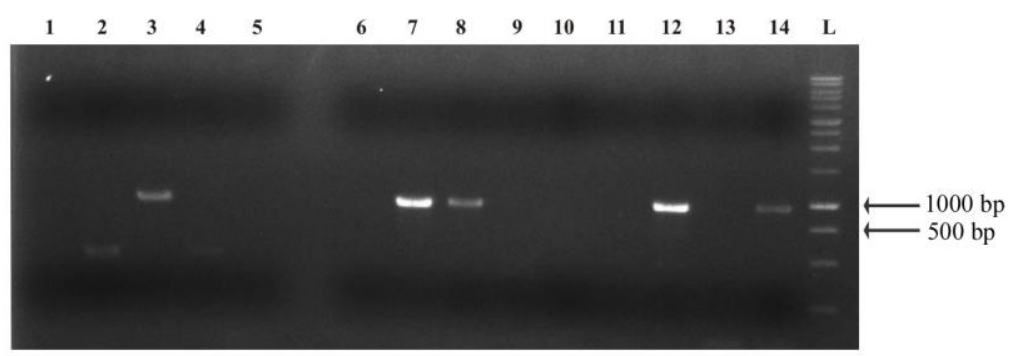

Figure 3. PCR amplicons of specific primers sprl $f$ \& $r$ for $F$. oxysporum f. sp. radicislycopersici isolates

Lanes L: DNA size marker, 1: Fu7, 2: Fu 33, 3: Fu 32, 4: Fu 34, 5: Fu 37, 6: Fu 22, 7: Fu 23, 8: Fu 25, 9: Fu 29, 10: Fu 60, 11: Fu 12, 12: Fu 19, 13: Fu 20, 14: Fu 76 


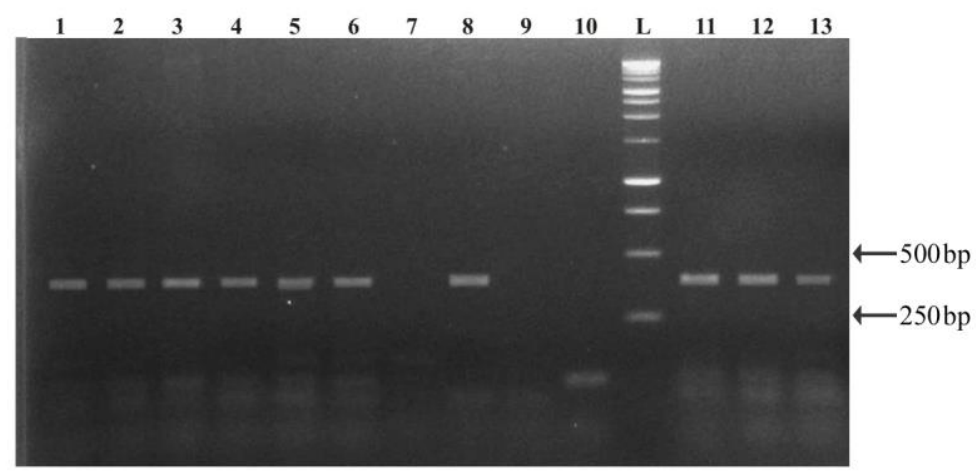

Figure 4. PCR products resulted in by specific primers (sp $13 \mathrm{f} \& \mathrm{r}$ ) to detect races of $F$. oxysporium f. sp. lycopersici isolates

Lanes L: DNA size marker 1: Fu 32, 2: Fu 33, 3: Fu 34, 4: Fu 37, 5: Fu 7, 6:

Fu 12, 7: Fu 19, 8: Fu 20, 9: Fu 76, 10: Fu 23, 11: Fu 22, 12: Fu 29, 13: Fu 60

Table 4. Results of homology search of selected Fusarium isolates

\begin{tabular}{|c|c|c|c|c|c|}
\hline $\begin{array}{l}\text { Isolate } \\
\text { No. }\end{array}$ & $\begin{array}{l}\text { Best homologue given by } \\
\text { BLAST }\end{array}$ & $\begin{array}{c}\text { Query } \\
\text { coverage } \\
(\%)\end{array}$ & E value & $\begin{array}{l}\text { Identity } \\
\text { ( \%) }\end{array}$ & $\begin{array}{c}\text { Sequence ID of } \\
\text { the best } \\
\text { homologue }\end{array}$ \\
\hline Fu 19 & $\begin{array}{l}\text { Fusarium oxysporum f. sp. } \\
\text { radicis lycopersici pgx } 4\end{array}$ & 95 & 0.0 & 96 & AB256796.1 \\
\hline Fu 29 & $\begin{array}{l}\text { Fusarium oxysporum f. sp. } \\
\text { trachephilum pq1 }\end{array}$ & 100 & 0.0 & 98 & MAFF235726 \\
\hline Fu 33 & $\begin{array}{l}\text { Fusarium oxysporum f. sp. } \\
\text { eustomae fuslis 31/09 }\end{array}$ & 96 & 0.0 & 97 & KJ361536.1 \\
\hline Fu 60 & $\begin{array}{l}\text { Fusarium oxysporum f. sp. } \\
\text { lycopersici FOL } 14\end{array}$ & 95 & 0.0 & 97 & KP404108.1 \\
\hline Fu 40 & Fusarium solani TRR-1 & 99 & e-137 & 97 & KY659068.1 \\
\hline
\end{tabular}

Based on the molecular identification, it is clear that different Fusarium species (i.e. F. oxysporum and F. solani) and several formae speciales of $F$. oxysporum (i.e. f. sp. radicis lycopersici, f.sp. trachephilum, f.sp. eustomae fuslis and f.sp. lycopersici) are responsible for the development of wilt in tomato and brinjal in Sri Lanka (Table 3).

\section{Isolation of endophytic bacteria}

Thirty endophytic bacterial isolates were isolated from healthy tomato and brinjal stems, namely 5 isolates from Kandy, 2 from Nuwara Eliya, 11 from Matale and 12 from Badulla districts. Results of the $3 \% \mathrm{KOH}$ test revealed that 26 out of the 30 bacterial endophytes were Gram negative. 
In vitro screening of antagonistic endophytic bacteria against pathogenic Fusarium isolates

Results revealed that 10 out of the 30 bacterial endophyte isolates which were tested for their antagonistic ability against Fu 60 isolate (F. oxysporum f. sp. lycopersici) showed more than $30 \%$ inhibition of the fungal colony growth. The bacterial endophytes which gave more than $30 \%$ colony growth inhibition of Fu 60 were further tested against $F$. oxysporum f. sp. trachephilum (Fu 29) and F. solani (Fu 11). Results presented in Table 5 indicate that all tested bacterial endophytes showed varying levels of inhibitory effect against the growth of the two F.oxysporum formae speciales (Fu 29 and $\mathrm{Fu} \mathrm{60)}$ and F. solani (Fu 11). Among the ten isolates, six coded as E 2, E 7, E 8, E 10, E 24 and E 25 were found to be highly antagonistic (50 - 67\%) against three Fusarium isolates (Fu 29, Fu 60 and Fu 11).

Table 5. Percentage mycelia growth inhibition of different Fusarium species by different endophytic bacterial isolates under in vitro conditions

\begin{tabular}{lllll}
\hline $\begin{array}{l}\text { Endophyte } \\
\text { isolate }\end{array}$ & Location & $\begin{array}{c}\text { F. oxysporum f. } \\
\text { sp. trachephilum }\end{array}$ & $\begin{array}{c}\text { F. oxysporum f. } \\
\text { sp. lycopersici }\end{array}$ & F. solani \\
\hline E 2 & Gannoruwa & $54.95^{\mathrm{bc}}$ & $48.17^{\mathrm{de}}$ & $51.85^{\mathrm{a}}$ \\
E 7 & Divithotawela & $49.15^{\mathrm{c}}$ & $61.80^{\mathrm{b}}$ & $51.48^{\mathrm{a}}$ \\
E 8 & Divithotawela & $64.51^{\mathrm{ab}}$ & $57.02^{\mathrm{c}}$ & $50.19^{\mathrm{a}}$ \\
E 10 & Helahalpae & $64.51^{\mathrm{ab}}$ & $47.33^{\mathrm{e}}$ & $55.55^{\mathrm{a}}$ \\
E 14 & Helahalpae & $29.73^{\mathrm{e}}$ & $29.71^{\mathrm{f}}$ & $29.89^{\mathrm{c}}$ \\
E 17 & Naula & $34.44^{\mathrm{d}}$ & $34.17^{\mathrm{g}}$ & $33.39^{\mathrm{c}}$ \\
E 19 & Hathotaamuna & $33.36^{\mathrm{d}}$ & $46.12^{\mathrm{e}}$ & $30.19^{\mathrm{c}}$ \\
E 24 & Pallepola & $67.74^{\mathrm{a}}$ & $50.37^{\mathrm{c}}$ & $51.59^{\mathrm{a}}$ \\
E 25 & Pallepola & $61.29^{\mathrm{b}}$ & $64.70^{\mathrm{a}}$ & $50.00^{\mathrm{a}}$ \\
E 26 & Udadelthota & $32.99^{\mathrm{f}}$ & $42.51^{\mathrm{d}}$ & $39.43^{\mathrm{b}}$ \\
Control & & $0.00^{\mathrm{i}}$ & $0.00^{\mathrm{f}}$ & $0.00^{\mathrm{d}}$ \\
\hline CV & & 3.13 & 2.15 & 6.29 \\
LSD & & 2.14 & 1.46 & 4.07 \\
\hline * Means in a column followed by same letter do not significantly differ according to LSD Test $(P<0.05)$
\end{tabular}

* Means in a column followed by same letter do not significantly differ according to LSD Test $(P<0.05)$

\section{Molecular identification of endophytic bacteria}

Results of homology search revealed the best matching organisms for endophytic isolates $\mathrm{E}$ 2, E 7, E 8, E 10, E 24 and E 25 are Pseudomonas geniculata strain (E 2), Bacillus velezensis strain C19 (E 25), Pseudomonas sp. strain SB 904 (E 7), Delftia tsuruhatensis (E 8), Stenotropomonas maltophilia strain ATCC 13637 (E 10) and Stenotropomonas pavanii strain ICB 89 (E24), respectively.

Based on previous research by Rania et al. (2016), Stenotrophomonas maltophilia str. S37 isolated from Datura stramonium exhibited 44\% inhibition of Fusarium oxysporum f. sp. lycopersici. Further, Bacillus species have reported strong inhibition of Fusarium oxysporum, over $70 \%$ mycelia growth reduction compared to control treatment under in vitro conditions (Narayan et al., 2013). Wang et al. (2016) have reported that Bacillus amyloliquefaciens can show growth promotion and antagonistic activity through the production of antifungal lipopeptides and volatile compounds against $F$. oxysporum. 
Table 6: Results of homology search of endophytic bacterial isolates

\begin{tabular}{llllll}
\hline $\begin{array}{l}\text { Isolate } \\
\text { No. }\end{array}$ & \multicolumn{1}{c}{ Blast research results } & $\begin{array}{l}\text { Query } \\
\text { covera } \\
\text { ge (\%) }\end{array}$ & E value & $\begin{array}{c}\text { Identity } \\
\text { ( \%) }\end{array}$ & $\begin{array}{c}\text { Sequence } \\
\text { ID }\end{array}$ \\
\hline E2 & Pseudomonas geniculata strain ICPH - 14 & 99 & 0.0 & 96 & KX611373.1 \\
E7 & Pseudomonas sp. strain SB 904 & 96 & 0.0 & 95 & MG491639.1 \\
E8 & $\begin{array}{l}\text { Delftia tsuruhatensis strain MTQ } \\
\text { E10 }\end{array}$ & 97 & $4 \mathrm{e}-10$ & 86 & HQ143604.1 \\
& $\begin{array}{l}\text { Stenotropomonas maltophilia strain } \\
\text { ATCC 13637 }\end{array}$ & 81 & $3 \mathrm{e}-116$ & 93 & NR112030.1 \\
E24 & Stenotropomonas pavanii strain ICB 89 & 97 & 0.0 & 96 & NR116793.1 \\
E25 & Bacillus velezensis strain C19 & 99 & $0-0$ & 98 & KU681039.1 \\
\hline
\end{tabular}

Pseudomonas geniculata, a Gram negative bacterium isolated from chickpea has reported its ability to promote plant growth (Gopalakrishnan and Sirinivas, 2015). Several previous studies have shown that Stenotrophomonas maltophilia isolated from Datura stramonium, plays important roles in agricultural production as a plant growth-promoting bacterium, which could suppress disease development by secretion of antibiotics such as maltophilin and xanthobaccin which have antifungal activity, however is inactive against bacteria (Rania et al., 2016). Stenotrophomonas pavanii (E24) isolated from Brazilian sugarcane is an endophytic bacterium that is capable of nitrogen fixation (Patricia et al., 2011). Bacillus velezensis (E25) (Bacillus amyloliquefaciens subsp. plantarum) is a plant-associated bacterium, which stimulates plant growth and produces secondary metabolites that suppress soil-borne plant pathogens. Therefore, the endophytic bacterial isolates of the present study agrees with the identity of previous reports related to potential endophytic bacteria of Fusarium spp. However, S. maltophilia has also been reported as nosocomial opportunistic pathogens (Mukhopadhhyay et al., 2003), hence, caution is needed when selecting potential endophytic bacterial antagonists for in vivo studies, though they are effective under in vitro conditions.

\section{CONCLUSIONS}

The present study identified the causal pathogens of Fusarium wilt of tomato and brinjal as Fusarium solani and Fusarium oxysporum f. sp. lycopersici. Molecular identification revealed the presence of four formae speciales, namely lycopersici, radices-lycopersici, trachephilum and eustomae in infected plants. All the isolates of Fusarium oxysporum f. sp. lycopersici identified in the present study belong to Race 1 and it is the first report from Solanaceous crops grown in Sri Lanka. The Endophytic bacterial isolates which were identified as Pseudomonas geniculata strain (E2), Bacillus velezensis strain C19 (E 25), Pseudomonas sp. strain SB 904 (E7), Delftia tsuruhatensis (E8), Stenotropomonas maltophilia strain ATCC 13637 (E10) and Stenotropomonas pavanii strain ICB 89 (E24) were potential antagonists of Fusarium oxysporum f. sp. lycopersici and Fusarium solani.

\section{REFERENCES}

Abeysinghe, S. (2007). Biological control of Fusarium solani f. sp. phaseoli the causal agent of root rot of bean using Bacillus subtilis CA32 and Trichoderma harzianum. Ruhuna Journal of Science. 2, 82-88. 
Can, C., Yucel, S., Korolev, N. and Katan, T. (2004). First report of Fusarium crown and root rot of tomato caused by Fusarium oxysporum f.sp. radicis-lycopersici in Turkey. J. Plant Path. 53, 814-814.

Gao, F. K., Dai, C. C. and Liu, X. Z. (2010). Mechanism of fungal endophytes in plant protection against pathogen. Afr. J. Microbiol Res. 4(13), 1346-1351.

Gopalakrishnan, S. and Sirinivas, V. (2015). Plant growth promoting traits of Psudomonas geniculata isolated from chick pea nodules. Biotech. 5(5), 653-661.

Grover, A., Chakrabarti, S.K., Azmi, W. and Khurana, S.M.P. (2012). Rapid method for isolation of PCR amplifiable genomic DNA of Ralstonia solanacearum infested in potato tubers. Adv. Microbiol. 2, 441-446.

Hirano, Y. and Arie, T. (2006). PCR-based differentiation of Fusarium oxysporum ff. sp. lycopersici and radicis-lycopersici and races of F. oxysporum f. sp. lycopersici. J. Gen. Plant Path. 72: 273-283.

Irzykowska, L., Bocianowski, J., Waskiewicz, A., Weber, Z., Golinski, P., Karolewski, Z., Kostecki, M. and Irzykowski, W. (2012). Genetic variation of Fusarium oxysporum isolates forming fumonisin B1 and moniliformin. J. Appl. Gen. 53, 237-247.

Khosrow, C. (2016). Molecular identification of pathogenic Fusarium species, the causal agents of tomato wilt in western Iran. J. Plant. Prot. Res. 56, 143-148.

Maitlo, S.A., Syed, R.N., Rustmani, M.A, Khuhro, R.D. and Lodhi, A.M. (2016). Influence of inoculation methods and inoculum levels on the aggressiveness of Fusarium oxysporum f.sp ciceris on chickpea and plant growth. Int. J. Agric. Biol.18, 31-36.

Mukhopadhyay, C., Bhargava, A., Ayyagari, A. (2003). Novel nosocomial infections by Stenotrophomonas maltophilia: First reported case from Lucknow, North India. J. Clin. Microbiol. 41, 3989-3990.

Narayan, C. P., Jianxin, X. D., Young, S. K., Bong,S. Y. and Seung, H. Y. (2013). Biocontrol activity of Bacillus amyloliquefaciens CNU114001 against fungal plant Diseases. Mycobiology. 41(4), 234-242.

Patrícia, L.R., Trappen, S.V., Thompson, F.L., Rafael, C.S.R. and Heloiza, R.B. (2011). Screening for endophytic nitrogen fixing bacteria in Brazilian sugar cane varieties used in organic farming and description of stenotrophomonas Pavani sp.nov. Int. J. Syst. Evol. Microbiol. 61(4),926-931.

Pavlou, G.C. and Vakalounakis, D.J. (2005). Biological control of root and stem rot of green house cucumber, caused by Fusarium oxysporum f. sp. radicis-cucumerinum, by lettuce soil amendment. Crop Protection. 24, 135-40. 
Purnawati, A., Sastrahidayat, I. R., Abdul, L. A. and Hadiastono, T. (2014). Endophytic Bacteria as Bio control Agents of Tomato Bacterial Wilt Disease. J. Trop. Life Sci. 4(1), 3336.

Rania, A.B.A., Jabnoun,K.H., Nefzi, H., Mokni-Tlili, S. and Daami,R. M. (2016). Endophytic bacteria from Datura metal for plant growth promotion and bioprotection against Fusarium wilt in tomato. Biocontrol Sci Technol, 26 (8), 1139-1165.

Sun, L., Qiu, F., Zhang, X., Dai, X., Dong, X. and Song, W. (2008). Endophytic bacterial diversity in rice (Oryza sativa L.) roots estimated by $16 \mathrm{~S}$ rDNA sequence analysis. Microb Ecol. 55, 415-424.

Vethavalli, S. and Sudha, S.S. (2012). In Vitro and in silico studies on biocontrol agent of bacterial strains against Fusarium oxysporum f.sp. lycopersici. Res Biotechnology. 3, 22-31.

Wang, B., Shen, Z., Zhang, F., and Shen, Q. (2016). Bacillus amyloliquefaciens Strain W19 can Promote Growth and Yield and Suppress Fusarium Wilt in Banana Under Greenhouse and Field Conditions. Pedosphere 26(5). 733-744. 